\title{
O LITERAL E A SURPRESA: OS "ESTÁGIOS PRELIMINARES DO CHISTE"
}

Ana Beatriz Freire e Carlos Alberto Ribeiro Costa

Ana Beatriz Freire
Professora associada
ao programa de
pós-graduação
do Instituto de
Psicologia da
UFRJ em Teoria
Psicanalítica;
pós-doutora pela
Universidade
Paris VIII, França;
psicanalista,
correspondente da
Escola Brasileira de
Psicanálise (EBP).
Carlos Alberto Ribeiro
Costa
Doutorando do
Programa em Teoria
Psicanalítica da
UFRJ; supervisor
de estágio do
Hospital de custódia
e tratamento
psiquiátrico
Heitor Carrilho;
psicanalista.

Ana Beatriz Freire

Professora associada Psicologia da UFRJ em Teoria Psicanalítica pós-doutora pela Universidade Paris VIII, França psicanalista, correspondente da Escola Brasileira de Carlos Alberto Ribeiro Costa Doutorando do Programa em Teoria Psicanalítica da UFRJ; supervisor de estágio do Hospital de custódia e tratamento psicanalista.
RESUMO: Vai-se discorrer sobre a função que as intervenções humorísticas podem desempenhar no tratamento de psicóticos, ao apaziguar a incidência do pulsional e suscitar a tomada de palavra por aqueles cuja existência não é balizada pelo falo. Para tanto, partiu-se da referência ao "chiste", efeito humorístico freudiano por excelência. A hipótese que aqui se desenha é a de que as vicissitudes econômicas relacionadas ao chiste, mesmo em seus estágios preliminares, podem esclarecer se e como tais intervenções podem ser efetivas num tratamento possível da psicose.

Palavras-chave: Tratamento da psicose, chiste, psicanálise.

ABSTRACT: The literal and the surprise: the preliminary stages of the wit. The target of this text is to explain in which way some humoristic interventions could help in the treatment of psychotic patients, pacifying the incidence of the "pulsional" and making the person, whose existence is not limited by the phallus, to start using speech. With this aim, our starting point was the mentioning of a "wit", or joke, the humoristic effect, which is Freudian by excellence. The hypothesis that we foresee is that the economic mishaps related to the wit, even on their preliminary stages, could clarify if and how such interventions could be effective in a possible treatment of psychosis.

Keywords: Psychosis's treatment, wit, psychoanalysis. 
$\mathrm{C}$ om andar hesitante e olhar repleto de profunda desconfiança, ambos nascidos de um corpo enrijecido e mecanizado, chegou a nós a paciente $\mathrm{S}$. Em suas primeiras sessões ela relata os acontecimentos que se desdobraram por ocasião do desencadeamento de sua psicose. É ao final de um destes encontros que $\mathrm{S}$ surpreende-nos ao dizer que, a despeito de os atendimentos estarem sendo de grande valia, ela não quer mais retornar. Perguntada a respeito, ela justifica: "É que me faltam as palavras." Nossa intervenção, correlata ao desejo de que algo do discurso analítico pudesse ali incidir, foi dizer: "As palavras, nós encontramos juntos. O que você acha?" Com um sorriso um bocado sem graça, S aquiesce à intervenção.

Na sessão seguinte, esta paciente conta, com um riso tenso, o que disse à amiga: "Meu Deus, agora tenho que achar palavras para dar nas sessões!" Curioso foi o efeito que então se deu e que surpreendeu tanto a nós quanto a paciente: um riso escapou de nossa boca. Ela, rindo por ricochete, conclui que, apesar de lhe faltarem as palavras, gostaria de falar nas sessões sobre os "ciúmes neuróticos" que tinha de seu marido e que, até hoje, a faziam sofrer. A perturbadora tensão, misto de desconfiança e "timidez" — como ela mesma o diz — se desloca da solitária descrença, a Unglauben, para o campo da palavra.

Intrigante alteração é esta, surgida de uma intervenção que se deu à revelia da intenção do analista e que, por seu caráter enigmático, nos instiga, a posteriori, a colher os efeitos e conseqüências de sua ocorrência.

Partindo de fragmentos clínicos como o que acabamos de relatar, mister se faz, para nós, “encontrar palavras” e, assim, falar do lugar que o humor pode ocupar para o tratamento da psicose. Nesta empreitada, uma questão será nossa guia: como este tipo de intervenção humorística pode incidir no atendimento a pacientes psicóticos, apaziguando a incidência do pulsional e propiciando uma tomada de palavra, exercício ético tão difícil de ser levado a cabo pelo louco?

Tentando equacionar esta questão, utilizaremos a referência ao fenômeno humorístico freudiano por excelência, a saber, o chiste. A hipótese que aqui se desenha é a de que as vicissitudes econômicas inerentes ao chiste podem nos esclarecer a respeito da efetividade que as intervenções humorísticas podem desempenhar na psicose.

\section{OS CHISTES NA PERSPECTIVA PSICANALİTICA}

Comecemos, então, aqui, por chamar a atenção para aquilo que em seu Os chistes em sua relação com o inconsciente, Freud propõe como sendo característico das tiradas. Sob o título "Parte analítica”, ele construiu uma sessão inteira de seu livro que consiste em analisar 'o chiste pelo chiste'. Por meio da análise detida destes fenômenos, foi possível atingi-los em sua coerência interna e não a partir de algo que lhe é estranho. Ora, tal atitude marca, de início, um corte com relação à 
abordagem até então dispensada ao tema. Nela, o chiste era, a priori, subordinado: 1) ao cômico, seja como caricatura ou como o simples desvelar de algo escondido; 2) à intencionalidade, em que esse é pensado como contraste ou jogo entre "idéias"; ou, ainda, 3) à satisfação contemplativa e desinteressada do "espírito" no gracejo. O desmonte destes a priori lançará luz sobre nossa questão.

\section{Os chistes e o cômico}

Ao examinar as posições que os autores (filósofos e poetas) assumiam a respeito dos chistes, Freud pôde concluir que se tendia, constantemente, a incluir o chiste na esfera do cômico. Entretanto, seja no interior da argumentação destes autores seja na relação das diversas argumentações entre si, era nítida a dificuldade de se estabelecer tal equivalência. O caráter dual, entre "agente" e "objeto", no cômico, em sua imanência ao enunciado, mostrava-se insuficiente para explicar o chiste, que implica, sempre, um além do texto da caricatura.

O desvelar do mesmo, por vezes feito de forma caricatural, é, também, algo próprio ao cômico e que se contrapõe à surpresa inerente ao chiste. Deste modo, o belo pode se mostrar em verdade feio e o esperto pode revelar-se de fato patético, mas se trata, no cômico, sempre da busca do mesmo.

O que os autores citados por Freud não explicitavam, mas que não deixavam de fazer era, sempre, pensar o chiste naquilo em que este se diferenciava do cômico. Assim, o novelista Jean-Paul Richter propunha tratar-se, no chiste, não só de uma dualidade, mas de um "jogo com as idéias". Theodor Lipps, filósofo, pensava o chiste, ao contrário de Richter, como o contraste entre "sentido" e "contra-senso". Mesmo Kant opinou sobre este curioso assunto, tratando o chiste como a passagem do "desconcerto" ao "esclarecimento".

A conclusão freudiana, portanto, não poderia ser diferente: a redução do chiste ao cômico não condiz com a tentativa de se encontrar algo específico da tirada espirituosa.

Esta dualidade imanente ao cômico tampouco auxilia-nos a pensar o fragmento clínico do qual partimos: neste, S não riu — como agente — de nós - enquanto um objeto. A paciente riu "conosco", de modo que a palavra, posta em ato, alterou a disposição daqueles dois corpos ali presentes. Como seria possível, mesmo em se tratando de psicose, reduzir tal efeito a uma dualidade?

Ora, a diferença entre rir de e rir com, especificamente na clínica das psicoses, torna-se mais evidente a partir de outro fragmento clínico: um caso de Gabriel Lombardi apresentado Conciábulo de Angers (MILLER, 2005) - "Efeitos de surpresa nas psicoses". Tratava-se, na ocasião, do relato de um caso de esquizofrenia-catatonia, acompanhado por este analista durante nada menos que 14 anos e que fora nomeado "Cura de um mutismo". 
Durante muitos anos o paciente se encontrava aferrado a seu leito de internação. Sua inatividade era escandida apenas em dois momentos: 1) aqueles em que ele cuspia na parede diante de sua cama; e, 2) aqueles em que, num arroubo, ele dizia: "Vejo pontinhos”. De início, a presença do analista desencadeou o surgimento de uma demanda de ajuda — "não ver pontinhos". À medida que o tratamento teve seus desdobramentos, o paciente passou a revelar as razões dos "risos imotivados" que, neste ínterim, haviam surgido.

Tomando o analista como figura "cômica”, ele caçoa da calça amarrotada e dos cabelos despenteados de Lombardi. Certa vez, na presença de sua mãe, o paciente diz:

“Aos psicólogos e psiquiatras agrada que os loucos falem de sexo - diz rindo. Remetem tudo ao sexo. Eu não tenho relações sexuais, nunca as tive, e não quero tê-las nunca. Logo, não me compreendem. Os psicólogos e os psiquiatras nunca entendem os loucos." (MILLER, 2005, p.120)

Este tipo de approach diz respeito ao que freudianamente podemos considerar como sendo da esfera do cômico; o paciente, agente da zombaria, ri "de" seu analista, objeto do escárnio.

O analista, ao mostrar-se surpreso, surge como um suporte deste enlace mínimo, que segue rumo a uma outra alteridade: a dritte Person freudiana. De fato, desde então, o paciente passa a fazer chistes, a mais social das formações do inconsciente. Nestes, ele ri de si mesmo; ao fazer piadas de judeu (sua religião), este psicótico brinca com sua condição. Aqui, o paciente ri não de, mas com seu analista. Seja ao rir de si, seja ao fazer piadas e trocadilhos, o paciente ri a partir do riso do Outro - alojado como alteridade possível. Surgem, então, duas perguntas: 1) como pensar este fazer que se dá à revelia da intenção do analista no chiste; e, 2) como esta surpresa catalisa a passagem ao outro do laço social?

\section{A não-intencionalidade e a literalidade do chiste}

“... é muito duvidoso que uma pessoa que dá livre curso a um chiste conheça a precisa intenção deste” (FREUD, 1905/1987, p.124). Se o estudo das respostas que a tradição (filosofia e poética) reservava ao assunto levou Freud a se colocar contra a equivalência entre chiste e cômico, seria, por outro lado, de sua própria análise que surgiria o fundamento para depor contra a intencionalidade dos chistes. Sua análise se opõe à intencionalidade seja como "intenção de significação" — em que o sujeito seria o agente do chiste —, seja com relação ao conteúdo intencional — a idéia — ligada à tirada.

Partindo da atenção dispensada ao material do qual são feitas as tiradas, Freud vislumbra duas hipóteses para explicar a formação de um chiste e seu efeito de 
riso: ou estes ocorrem por meio das idéias contidas na sentença proferida, ou, ao contrário, é a própria sentença, em sua materialidade de verbo, aquilo em que reside o gracejo.

Pretendendo responder tal questão, Freud aponta como característica fundamental do chiste a "brevidade", o fato deste se dar em "palavras poucas demais, insuficientes para a lógica restrita do pensamento usual” (FREUD, 1905/1987, p.26). Em que, porém, a brevidade colaboraria para a escolha de uma das opções supracitadas? Ora, a resposta a esta questão reside no fato de que a tradução, a posteriori, das idéias supostamente condensadas no chiste não causa no ouvinte ou em quem o profere, seu efeito risível. A substituição das expressões lingüísticas por pensamentos, numa explicação, faz desaparecer o caráter e o efeito do chiste. São, pois, características dos chistes tanto a literalidade — seu aspecto de letra - quanto a economia "de palavras" e "com as palavras" que este veicula.

Por outro lado, a expressão sintática feita presente no chiste (e não a idéia que lhe corresponderia) torna presente, ainda, outra peculiaridade: ela evoca, por uma espécie de articulação, outra expressão que jaz referida ou implícita sob a forma verbalizada. Isto se faz nítido pela análise do chiste de Heine, tornado ainda mais célebre por Freud, aquele que se refere ao termo "familionarmente".

Freud conta que Heine, em seu livro Reisebilder, faz proferir um excelente chiste, pela boca de seu personagem Hirsch-Hyacinth. Narrando ter estado, em determinada situação, ao lado do rico Barão Rothschild, Hyacinth diz: "E tão certo como Deus há de me prover todas as coisas boas, Doutor, sentei-me ao lado de Salomon Rothschild e ele me tratou como um igual — bastante familionarmente".

Nesta sentença condensam-se outras duas: 1) Rothschild tratou-me de forma familiar; e, 2) Rothschild tratou-me como um milionário. A expressão familionär, que não existe no código da língua alemã, é construída, então, de forma a fazer uma dupla alusão, tanto à palavra familiär quanto à palavra milionär. Esta possibilidade é dada, assim, pela coincidência entre os sons das letras "m-i-li” presentes em ambas as palavras. Freud chega, a este respeito, a fornecer um esquema de tal chiste:

$$
\begin{aligned}
& \begin{array}{l}
\text { famili är } \\
\text { milionär }
\end{array} \\
& \text { familionär }
\end{aligned}
$$

Algo similar nos aconteceu com uma de nossas pacientes que, ao contrário de $S$, era neurótica. $B$, frente ao dilema colocado por seu parceiro que, por sua postergação, não permitia que a relação entre eles ascendesse ao patamar de 
matrimônio, profere — surpreendendo-se com o que diz — a seguinte sentença: “Apesar de tudo, fico feliz por ainda tê-lo como "namorido”. A condensação entre os termos 'namorado' e 'marido', amparada pelas letras 'm', 'r', ‘d', e 'o', exigiu, de nossa parte, o riso sinalizador que este dizer merecia. A surpresa do encontro com a verdade, a partir do desencontro no dito, fez valer o aspecto faltoso e traumático do real de maneira risível e apensa ao laço social.

Haveria, deste modo, nos chistes, a referência a uma "outra cena" — um topos - através e para além do texto do enunciado. Nos dois exemplos acima citados, há a dupla necessidade de autorizar esta mensagem "para além do código": por um lado a expressão "comprime” duas expressões que não estão presentes no enunciado; por outro, termos como "familionär" e "namorido" não existem, em alemão e português. É preciso, pois, um uso do código em que o falante, ao mesmo tempo, se submeta e subverta o material da língua - tendo por referência: os sinais e não o pensamento; e, lugares que se constituem a partir do instante da enunciação.

Foi por exemplos como estes que Freud concluiu que "não pode haver dúvidas de que é precisamente desta estrutura verbal que dependem o chiste e o seu poder de causar riso” (FREUD, 1905/1987, p.27). Para além da intenção de significação - em que o sujeito seria causa do chiste - e do conteúdo intencional — em que este geriria os pensamentos — é “espírito” o que advém, e não o que causa esta atividade.

\section{Os chistes e a surpresa na neurose e na psicose}

No exemplo em que se formou o termo "namorido", o recalcado, ao retornar para a paciente no circuito de fala instaurado pela relação analítica, a surpreende e a ruboriza. Seu riso, a partir do riso do analista, acusa o recebimento da mensagem de B sob uma forma invertida. O esquema $£$, construído por Lacan em 1955, tem por função explicitar este funcionamento: no pólo em que se desenrola a intenção de significação — eixo a-a' em que o falante se crê senhor de sua palavra - intervém o Outro, a dritte Person freudiana, como corte que desvela sua verdade e seu gozo. Este corte, ligado à incidência simbólica e real do significante sobre o falante, o surpreende por sua não-intencionalidade.

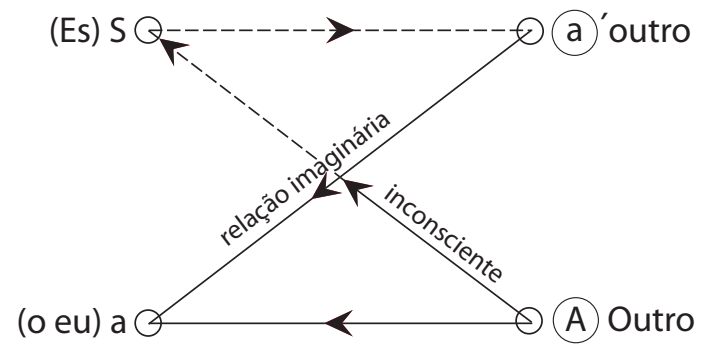


Se isto é assim nas neuroses, como pensar a alteridade, o topos e a literalidade dos chistes para o psicótico, “desabonado do inconsciente”? Que lugar tem a "surpresa” naquilo que retorna do campo do Outro nas psicoses?

Em seu seminário sobre as psicoses, Lacan dirá que tudo se passará para o psicótico, “a partir do momento em que a iniciativa vem de um Outro” (LACAN, 1955-56/1988, p.220). Nestes casos seria, pois, como se para o enigma posto pelo inconsciente a resposta tivesse sido dada antes da pergunta, ou, ainda, como Lacan também julgara possível dizer, seria como se a pergunta tivesse se colocado, para o sujeito na psicose, sozinha:

“Estamos certos de que os nevrosados se puseram esta questão. Os psicóticos, não é tão certo. A resposta lhes veio antes da questão - é uma hipótese. Ou então a questão se pôs sozinha — não é impensável." (LACAN, 1955-56/1988, p.230)

Se o enigma do Outro depende de uma pergunta para se fazer presente enquanto lugar da verdade do sujeito, nos casos de psicose o significante se impõe ao louco como injunção de um gozo absoluto, cujos resultados são a alucinação, o delírio, as dissoluções, etc. Logo, a surpresa nas psicoses - a perplexidade - está atrelada a este encontro com o real sem o amparo do laço social. Lacan chamou tal condição de 'foraclusão'.

Nos anos 1950, época de elaboração do esquema $£$ e advento da noção de foraclusão, Lacan utiliza um exemplo clínico que explicita a perplexidade que advém do encontro do sujeito com sua mensagem que retorna no real: trata-se do caso em que uma paciente ouve a alucinação "Porca”. Esta mulher relata a Lacan que, certo dia, ao passar pelo amante de sua vizinha, escutara esta injúria. Quando perguntada sobre o que se passara por sua cabeça no momento anterior à imposição alucinatória ela diz ter pensado a seguinte sentença: "Eu venho do salsicheiro".

Para Lacan, a mensagem, aqui, não faz seu retorno através do campo do Outro; a paciente a recebe retornando no real, desde o (des) encontro com o amante de sua vizinha. Ele salienta, a respeito do momento de desencadeamento, que esta vizinha tinha o "mau hábito" de atrapalhar seus momentos a sós com sua mãe, com quem ela voltara a viver desde sua separação: por ocasião de seu casamento, a paciente reagira à ausência da mãe com a certeza de que, literalmente, lha cortariam em "rodelas" (LACAN, 1955-56/1988, p.61). O significante, não simbolizado e vindo de uma posição terceira, desencadeou a alucinação.

Este colapso, em que o Outro não simbolizado se impõe por meio de mensagens não articuladas — alucinações ou certeza delirante - é um exemplo do que Lacan chamou, em 1955, de fenômenos de mensagem, ou, mensagem interrompida. Em casos como estes, o significante que retorna sobre o falante 
não constitui uma cadeia que representa o sujeito pelo intervalo e referência a outro significante — operação-índice da gramática inconsciente. A presença que a mensagem interrompida torna atual envia, antes, a um significante desencadeado, externo a esta estrutura.

As formações do inconsciente, que implicam esta articulação estrutural, não podem, pois, ser tomadas como tais na relação falante-significante na psicose. O Outro como “outra cena”, como lugar da verdade do sujeito, é algo problemático na psicose. Como desabonado do inconsciente o psicótico pode, porém, fazer um uso da literalidade do chiste para, a partir dele, tratar o gozo, esboçando uma cessão de algo deste quantum ao campo do Outro. Esta é, por exemplo, a posição de Lombardi ao falar do lugar que o chiste ocupou no caso, por nós citado, "Cura de um mutismo":

"No caso que apresentei o chiste não desempenhou a função de formação do inconsciente, sobre a qual morde a interpretação, mas funcionou como um comutador no trabalho de transferência, transformando um gozo absoluto em algo que se verte no laço social, e se relativiza." (MILLER, 2005, p.167)

Os chistes exigem, pois, que o ouvinte sustente um Outro que não compareça como gozação - nem vontade de gozo, nem como o escárnio do agente sobre o objeto no cômico. A surpresa, aqui, encontra importante lugar: surpreendendo-se com as construções que lhe são endereçadas, o analista se ampara em seu não-tudo saber e se faz suporte e destinatário do dizer do psicótico. O analista, enquanto pelo menos um a não gozar do psicótico, utiliza o efeito de surpresa não como perplexidade, mas, sim, como catalisador posto à disposição do louco para a construção de alguma alteridade possível. Por meio desta operação com a palavra pode-se tratar o gozo - como Outro maciço ou significante desarticulado.

Nancy Katan-Barwell, em Conciábulo de Angers (MILLER, 2005), chama a atenção justamente para um dizer de Lacan em que se desvela como a surpresa pode ser um recurso, na intervenção do analista, para atingir o real da incidência do significante sobre o sujeito. Trata-se de um fragmento extraído de uma conferência proferida em 1967 por Lacan intitulada 'Da psicanálise em suas relações com a realidade': "Devemos surpreender algo cuja incidência original foi marcada como traumatismo” (LACAN, 1967). É, logo, num trabalho que não desconhece a faceta traumática e solitária do significante que a surpresa e o humor auxiliam na tecedura de um enlace pelo louco.

Ribeiro, em O R.I.S.O. na clínica das psicoses (2006), traz um fragmento que, segundo pensamos, ilustra esta união entre humor e surpresa. O riso, aqui, surpreende, ao mesmo tempo, sujeito e ouvintes, os descompletando. Mais que o desconcerto do louco ante a não-inscrição de sua mensagem vinda do 
Outro, o riso marca a inauguração de uma nova relação do psicótico com seu entorno social.

“O paciente não se sente capaz de estar com mulheres devido a pensamentos impuros e pecaminosos que, imperativamente, o invadem. Afirma que só os outros homens estão habilitados para tal tarefa. Em meio a uma discussão sobre os dez mandamentos bíblicos, na igreja evangélica que freqüenta, o sujeito decidiu confessar publicamente aquilo que considera seu maior pecado. Conta a todos que sua fraqueza consistia em olhar, e mais que isso, desejar, justamente, a mulher do próximo. Se a mulher não estiver acompanhada de um próximo, não lhe desperta nenhum sentimento. Todos na igreja se puseram a rir, inclusive o pastor. Ele resolveu perguntar o porquê das risadas e o pastor respondeu: 'Os que riram é porque a carapuça serviu!'. Na sessão, revela o que constatou das risadas e que lhe trouxe um enorme alívio: os outros homens também pecam, até mesmo o pastor.” (RIBEIRO, 2006, p.89)

Impõe-se, logo, pensar as vicissitudes econômicas implicadas no chiste, visto que a satisfação que advém na consolidação da tirada é um efeito capital desta máquina formal. De fato, em seu livro sobre o assunto, Freud diz que, nos chistes: “Tudo parece ser uma questão de economia” (FREUD, 1905, p.58). Mas como pensar, sem o recurso à gramática inconsciente, este trabalho do psicótico com a literalidade do significante em sua tomada de palavra e em seu tratamento do gozo?

\section{Os estágios preliminares do chiste}

A psicogênese dos chistes nos ensinou que o prazer em um chiste deriva do jogo com as palavras ou da liberação do nonsense e que o significado nos chistes pretende simplesmente proteger o prazer contra sua supressão pela crítica (FREUD, 1905, p.154).

Quando Freud, em seu livro de 1905, se debruça sobre a satisfação que resulta do chiste, ele averigua que, para a tradição, esta provém da atividade contemplativa, da fruição da idéia contida na tirada espirituosa. Freud, não obstante, conclui algo bem diverso. Para ele, o chiste não é uma atividade desinteressada. Para sustentar esta posição, ele partiu da divisão entre chistes ingênuos — quando a satisfação advém do próprio manejo do material — e chistes tendenciosos cuja satisfação resulta de um propósito "obsceno" ou "hostil”.

Não há mistério em propor que os chistes ditos "tendenciosos" permitem a satisfação de uma pulsão frente a um obstáculo: por meio deles pode-se dizer algo erótico ou agressivo a um objeto trazendo um ouvinte, como terceira pessoa, para o lado daquele que profere o chiste. Isto assim ocorre porque, como vimos, por sua lógica interna, o chiste exige esta terceira pessoa. Neste tipo de 
chiste - se o recalque, ou seja, a crítica, é o obstáculo que interfere na fruição deste gozo - pode-se atingir este objetivo por meio de um suborno do ouvinte (FREUD, 1905/1987, p.155). Suborna-se o ouvinte, em sua posição de Outro, por meio do prazer da risada. Mas e quanto aos chistes não tendenciosos? Estes não seriam feitos na ausência de um propósito, seja ele hostil ou erótico?

Ora, mesmo os chistes não tendenciosos trazem, como sua peculiaridade, o fato de advirem do manejo não das idéias, mas, sim, do material verbal de que são feitos. Isto, por si só, basta para revogar a pretensão de pensar a tirada como contemplação de idéias. Mas Freud acrescenta ainda que, em muitos chistes ingênuos, há um prazer extraído pelo sujeito no jogo com as letras e com o som sem sentido das palavras.

Nestes casos, ocorre, para Freud, que "a apresentação (acústica) da palavra toma o lugar de sua significação tal como determinada por suas relações com as representações das coisas" (idem, p.141). O "jogo" com a letra, usual na infância, dispensa de início a terceira pessoa e é abandonado à medida que o infante faz sua gradual entrada na cultura. Tal satisfação solitária, antes autorizada, deve ser "rejeitada e cuidadosamente evitada pelo pensamento sério" (idem, p.142). Enquanto a crítica exige o abandono do sem-sentido e do absurdo, os chistes "ingênuos", nos adultos, são tecidos com o intuito de aliciar a crítica e, assim, reaver algo deste gozo interditado. Eis o interesse que faz o sentido nascer do sem-sentido: proteger o gozo do nonsense "contra sua supressão pela crítica" (idem, p.154).

A consideração destes modos de relação entre falante e significante levou Freud a propor, então, dois "estágios preliminares do chiste" (idem, p.150), em que não há, ainda, o chiste como efeito da articulação do saber inconsciente.

O primeiro estágio é o "jogo”. Neste, a criança joga com as palavras advindas de sua língua materna para, através desta atividade, extrair satisfação da "similaridade do som", do "reencontro do familiar" e da "repetição do similar".

"O período em que uma criança adquire o vocabulário da língua materna proporciona-lhe um óbvio prazer de 'experimentá-lo brincando com ele', segundo as palavras de Gross. Reúne as palavras, sem respeitar a condição de que elas façam sentido, a fim de obter delas um gratificante efeito de ritmo ou de rima. Pouco a pouco esse prazer vai lhe sendo proibido até que só restam permitidas as combinações significativas de palavras." (idem, p.148)

Veremos que Lacan nomeou este gozo homofônico, aquém da estrutura e do sentido, de "alíngua".

O segundo estágio, o gracejo, é marcado pela exigência de que estes jogos com as letras façam sentido. Entre os dois estágios há a consideração pela interdição 
deste gozo do nonsense que, por parte da intervenção da crítica, deve tombar sob a barreira do recalque.

"O que distingue um gracejo de um chiste é que o significado da sentença que escapou à crítica não necessita ser válido, novo, ou mesmo bom; é simplesmente permissível dizer tal coisa daquela forma, ainda quando seja infreqüente, desnecessário ou inútil dizê-lo de tal forma. Nos gracejos o que figura em primeiro plano é a satisfação de ter tornado possível o que era proibido pela crítica." (FREUD, 1905/1987, p.164)

Não obstante, a experiência clínica, assim como a cotidiana, permitem-nos averiguar que o prazer no nonsense pode ter efeitos de laço antes mesmo da exigência de que Isso faça sentido.

Ainda em R.I.S.O. (2006), Ribeiro exemplifica isto pelos jogos partilhados pelas crianças:

“As crianças adoram brincar de roda ou de bater suas mãos nas mãos dos colegas, cantarolando músicas que utilizam o nonsense para gerar prazer. (...) Meninas que nasceram na Zona Sul do Rio de Janeiro, por exemplo, conhecem de cor cantigas repetidas e compartilhadas por amiguinhas nas escolas durante toda a infância e que podem ser reproduzidas assim: 'Dom-dom-baby-mama-salamica-yuyu-shakemama-salamica-geme-geme-yupapa-gemegeme-pá' ou 'enga-la-enga-lagosta-lagoêlagostemgogo-lagostalagoê-lagostempapa-lagostalagoê....” (RIBEIRO, 2006, p.33)

Logo, antes da incidência do recalque sobre a satisfação no nonsense, um enlace é possível a partir do manejo da letra.

Na esquizofrenia ocorre, segundo Freud, uma operação semelhante àquela em que a representação da palavra toma o lugar da representação das coisas, subjugando, assim, a significação pela literalidade. Do mesmo modo como Lacan o fez posteriormente em seu seminário sobre as psicoses, Freud, em seu artigo sobre o Inconsciente (1915), sublinha as peculiaridades da palavra endereçada pelo psicótico: “A construção de suas frases passa por uma desorganização peculiar, que as torna incompreensíveis para nós, a ponto de suas observações parecerem disparatadas" (FREUD, 1915/1987, p.202).

Mais adiante - amparado na descoberta clínica de que nas psicoses, ao contrário do que se dá nas neuroses de transferência, a libido retorna sob o eu do psicótico e não para a fantasia (FREUD, 1914/1987) — ele chama a atenção para o lugar que este manejo sui generis da letra pode ter na esquizofrenia:

“... a catexia da representação da palavra não faz parte do ato de recalque, mas representa a primeira das tentativas de recuperação ou de cura que tão manifestamente 
dominam o quadro clínico da esquizofrenia. Estas tentativas são dirigidas para a recuperação do objeto perdido, e pode ser que, para alcançar esse propósito, enveredem por um caminho que conduz ao objeto através de sua parte verbal, vendo-se então obrigadas a se contentar com palavras em vez de coisas.” (idem, p.208)

O analista, ao acolher estas construções como tentativas de cura, auxilia a conferir a este trabalho com a literalidade - ponto comum entre o dizer psicótico e os estágios preliminares do chiste - um estofo. O pas de sens, seja como "sem sentido" ou, ainda, como "passo de sentido” da letra na intervenção humorística, convoca o analista a ocupar um lugar perante este fazer lúdico com a sonoridade da letra desarticulada. Esta operação torna-se, assim, parte da questão preliminar a todo tratamento possível da psicose.

A consideração por estes jogos com a letra — que se desenha à revelia do sentido e alicerçado na homofonia — faria Lacan, entre 1971 e 1973, marcar um ponto de báscula em relação a seu ensino. Em detrimento da hipótese tecida nos anos 1950 - a saber, a de que o inconsciente é “estruturado como uma linguagem”, ele passará a propor nos anos 70, a noção de alíngua. Este termo, “alíngua”, surgiu no seminário de Lacan sobre ‘O Saber do psicanalista’. Na lição de 4 de novembro de 1971, a partir de um tropeço, Lacan "trocaria” o título do livro "Vocabulário de Psicanálise” por "Vocabulário de Filosofia” — de André Lalande. Lacan autentica seu ato falho e forja — à maneira de um chiste ingênuo, desde a homofonia com “Lalande”, a expressão “Lalangue”, ou, la (a) + langue (língua): alíngua.

Com este termo, Lacan designa um modo de relação entre falante e significante que remete, não à estrutura e à significância, mas, sim, ao gozo do verbo. A exemplo do que diz Freud, ou seja, que "a apresentação acústica toma o lugar do significado”, Lacan propõe, em ato, ao brincar ele mesmo com os sons das palavras, um estado do significante em que este mostra seus efeitos nonsense como “causa do gozo” (LACAN, 1972-3/1985, p.36). Causa de gozo, pois, inscrita a princípio de forma desarticulada na carne do falante, este "enxame de significantes" instaura, à medida que este se deposita, a "substância gozante" (idem, 35). Mas como se daria a passagem desta relação solitária do falante com o significante e o gozo em alíngua para o processo social que é o chiste?

Ora, o aparecimento do efeito sujeito na cena social apenas se dá à medida que, num passo ético, se constitui a renúncia pulsional que permite à criança se inscrever na cultura e articular, por meio de um jogo com os próprios fonemas, a "zorra das palavras".

Este passo fundamental foi sublinhado por Freud no ano de 1920, em Além do princípio do prazer, na análise que este faz do jogo da criança com os sons e com o carretel de linha: "A interpretação do jogo tornou-se então óbvia. Ele se relacionava à grande realização cultural da criança, a renúncia pulsional (isto é, 
a renúncia à satisfação pulsional) que efetuara ao deixar a mãe ir embora sem protestar" (FREUD, 1920/1987, p.27).

Os chistes ingênuos, construídos à base do jogo com os fonemas, trazem, então, a marca da renúncia deste gozo, mas, também, de sua busca, ainda que esta se dê, agora, por meio de uma satisfação substitutiva — que inclui a alteridade e a articulação significante. Os chistes são, pois, efeitos deste passo ético, deste “saber-fazer” (LACAN, 1969-70/1992, p.19) com o gozo no qual é o ouvinte, e não o sujeito, quem obtém a satisfação mais intensa.

O passo dado pelo sujeito da relação solitária do falante com o significante e o gozo em alíngua para o processo social que é o chiste, através de seus "estágios preliminares", pode ser exemplificado, também, por um último fragmento clínico: o percurso de Marina, uma adolescente autista em sua construção de uma alteridade possível.

Bastante avessa seja à abordagem direta ou a ações que excetuassem sua rotina, Marina inicia seu trabalho. Certo dia, ela pergunta: "O que você achou da história, Carla?". Desconhecendo a história de que se tratava sem, porém, deixar de acolher o que lhe era dirigido, a clínica pede que Marina mesma a conte: "Era uma vez uma acamada” — diz ela, interrompendo sua narrativa. A ouvinte pergunta: “Uma camada? Camada de quê?”. Marina continua: "Era uma vez uma acamada. O doutor Gogó chegou. Boa tarde, doutor Passarinho!!!!”. E, então, a clínica continua, pontuando: “Ah! Acamada!”. Surpreendidas pelo equívoco entre as expressões "a camada" e "acamada”, ambas caem na risada e experimentam, de forma risível, a incompletude inerente a este encontro faltoso.

Este jogo com a sonoridade, motor de uma satisfação partilhada entre Marina e Carla, motivou a clínica a impetrar outro trocadilho, desta vez com base em uma história na qual aparece um jogo semelhante com as palavras “pégaso” e “pega o azul”. Marina, até então avessa à fala da clínica, passou não apenas a repetir as frases da história mas, também, a experimentar neste jogo com os significantes do Outro, a satisfação do riso. Em seu percurso, Marina vai mais além e pede: "Vamos embaralhar?" — pondo-se, logo, a embaralhar as frases das duas histórias contadas, cortando e colando-as novamente.

Este trabalho lúdico efetivado por "Marina” reitera, aqui, a dimensão que estamos a asseverar ao longo de nosso texto; aquela do trabalho risível do sujeito sobre e com alíngua no tratamento da substância gozante. No caso específico do autismo, faz-se mister atentar para a importância deste "saber-fazer" posto que Lacan, em 1975, em sua Conferência de Genebra, chama a atenção justamente para o gozo da homofonia não mediado pelo objeto "voz", gozo este que o levaria, ali, a predicar os autistas como "verbosos".

Ao "embaralhar" a zorra das palavras, tratando o gozo do verbo, o autista pode construir um circuito pulsional mínimo que inclua algo do campo do Outro. 
O trabalho nos "estágios preliminares do chiste", como o nomeia Freud, ou o "saber-fazer" com alíngua, nas palavras de Lacan, diz respeito ao trabalho do falaser mesmo estando este "fora do discurso" e "desabonado do inconsciente".

\section{A QUESTÃO ÉTICA: A CESSÃO DE GOZO E A SURPRESA}

Há, logo, um operar lúdico e risível com a letra, que Freud chamou de "estágios preliminares do chiste". Este trabalho anterior ao recalcamento e à articulação inconsciente pode "comutar" a substância gozante fazendo passar algo deste quantum para um enlace com a alteridade. Duas exigências se impõem, porém, para que tal processo seja levado a seu termo: 1) que o sujeito ceda algo de sua "libra de carne”, ou seja, de seu gozo; e 2) que alguma alteridade autentique estes esforços. A experiência clínica que, ao longo de nosso texto, moveu nossas elucubrações, nos permitirá concluir o presente artigo com alguns exemplos de tal operação.

No caso de $\mathrm{S}$, que abriu a escrita deste texto, encontramos uma mulher às voltas com uma profunda descrença em relação à palavra e ao Outro. As idéias de perseguição, resistentes a sistematização — e também as alucinações — tornavam presentes para ela a face traumática do significante que não retorna por meio do circuito em que o sujeito recebe, do Outro, sua própria mensagem sob a forma invertida. Ante esta investida avassaladora do significante desarticulado a desconfiança surge como último recurso.

Destarte, em seu encontro com o analista, S diz "faltarem-lhe as palavras", o que, para ela, significava a eminência de abandonar o tratamento. Confrontada com a questão do desejo - que, neste caso, comparece por meio do desejo do analista de que algo do discurso psicanalítico ali interviesse - a paciente é tomada por um riso tenso. Entretanto, ao falar de sua história tendo como parceiro não um Outro onipotente que a avassala, mas um Outro capaz de ser surpreendido - por sua vontade de prosseguir ou não — , há uma cessão de algo do gozo solitário e refratário à alteridade em direção a este laço social mínimo que é o dispositivo clínico. O que esta mulher dá? A resposta: suas palavras.

O riso que escapa do analista e surpreende tanto a este quanto à paciente sinaliza a queda de algo da gozação entre sujeito e Outro. A surpresa evoca na sessão analítica, para parodiarmos Lacan, “algo cuja incidência original foi marcada como traumatismo” (LACAN, 1967). É partindo deste encontro faltoso entre sujeito e Outro, que se pode, a partir da escuta, construir uma dupla dessimetria: entre o louco e o objeto - em que se ri com o analista, não se tratando, pois, de escárnio - e, ainda, entre a satisfação que o louco experimenta como piadista e a do ouvinte, como "terceira pessoa”: à maneira dos chistes, é a terceira pessoa aquela que colhe, dos gracejos, a satisfação mais intensa.

Segundo pensamos, processo semelhante a este é aquele que se deu no caso relatado por Lombardi. Há, também aqui, algo, um objeto “caduco”, que cede 
entre ele e o paciente. De fato, a sofisticação destes objetos dá o roteiro do que ocorreu ao longo do tratamento. Às cuspidas, presentes desde o início, se sucede uma série de objetos: poemas, desenhos e, por que não?, o riso. O desprender de algo "corporal" advindo desde a catatonia, permite a este homem entrevado há sete anos numa cama, dirigir ao Outro algo de sua incompletude: insatisfeito com sua condição, ele pede ajuda para não mais "ver pontinhos".

Algo análogo ocorre no caso "Marina”: tratou-se, ali, também, de operar uma perda. Seja pelo desencontro que surpreende um Outro em vias de pacificação — no equívoco entre "acamada" e "a camada" —, seja no jogo de embaralhar, recortar e colar as palavras que lhe vem de uma alíngua intrusiva, algo da incompletude, de uma queda entre sujeito e Outro, insiste em buscar realização. Até então alojada em um lugar de objeto, Marina, agora, não mais se basta, neste lugar, a si mesma: da cessão de algo do gozo vocal nascem as palavras que ela utiliza para tecer um enlace com o Outro.

Este não se bastar a si mesmo é tido, por Freud, como condição econômica para que se estabeleça uma transferência. Em Dinâmica da transferência (FREUD, 1912/1987), ele afirma que "é perfeitamente normal e inteligível que a catexia libidinal de alguém que se acha parcialmente insatisfeito, uma catexia que se acha pronta por antecipação, dirija-se também para a figura do médico" (idem, p.134). A cessão de um quantum da incidência do pulsional, veiculada pelo trabalho com a letra e com o objeto encontra-se lado a lado com a intervenção humorística em ambos os casos.

Seriam estas cessões de palavras, cuspes, riso, etc. tentativas de extrair um objeto que insiste em coincidir com o louco? De todo modo, a surpresa do lado do analista aloja uma alteridade que não é toda saber e que, por isso mesmo, serve de suporte a este trabalho. O cume da construção não de um Outro intrusivo e desarticulado, mas, sim, social, ocorre quando a dessimetria própria à satisfação do chiste se efetiva no fato de ser o ouvinte e não o piadista quem experimenta satisfação mais intensa.

Neste caso, no horizonte do trabalho do psicótico, ainda que de forma assintótica, está a produção do objeto mais-de-gozar:

"Da perplexidade do gozo absoluto do sintoma passa, pela mediação da surpresa no Outro de transferência e também do chiste que a prolonga, a distração de seu gozo como Lustgewin [mais-de-gozar], gozo que busca produzir-se no Outro do laço social, e não no Outro do delírio. (...) A dimensão do surpreendente é aqui abertura ao social que, fora do discurso, deixa o sujeito na perplexidade." (MILLER, 2005, p.122)

Da mesma opinião é Ribeiro (2006) ao dizer que: 
“... é somente na medida que o sujeito consegue surpreender o Outro que ele colhe o prazer, aquele mesmo prazer que o sujeito infantil extraiu de seus primeiros usos do significante: 'O fenômeno da surpresa tem algo de originário' (LACAN, 1957-58: 97).” (RIBEIRO, 2006, p.47)

Logo, a intervenção humorística no tratamento da psicose aloja seu lugar no manejo da literalidade do significante, indo desde aquilo que Freud chamara de “estágios preliminares do chiste” até a construção assintótica do objeto a como objeto mais-de-gozar. À medida que certo grau de incompletude venha se apresentar perante a metonímia de gozo permite-se a construção de um destinatário que se coadune com a dritte Person freudiana.

A intervenção do analista, ao se deparar com a "transferência delirante" (LACAN 1956-57/1988, p.551) parece ser, assim, a de sustentar que este hiato, uma vez presente, se conserve. Se da parte do sujeito cabe a renúncia, em ato, da parcela pulsional a ser cedida, do outro lado do laço que é a escuta analítica, compete ao analista levar a cabo aquilo que, já em 1953, Lacan chamara de sua maior responsabilidade: ser ao menos um a não tomar o paciente como objeto e alojar, nisso, um lugar para o efeito sujeito:

“... a função decisiva de minha própria resposta (...) não é apenas, como se diz, a de ser aceita pelo sujeito como aprovação ou rejeição de seu discurso, mas realmente a de reconhecê-lo ou aboli-lo como sujeito. É essa a responsabilidade do analista toda vez que ele intervém pela fala.” (LACAN 1953, p.301)

Neste "saber-fazer" risível, neste humor louco alojado entre o lúdico e o estrutural, trata-se, para o sujeito, de se exercitar eticamente a partir do traumatismo que lhe constitui. Logo, tomar em consideração as vicissitudes pulsionais que se fazem presentes nos chistes, mesmo em seus estados preliminares, permite lançar alguma luz a respeito do que se passa nas intervenções humorísticas. É na medida que o psicótico experimenta, por meio da surpresa, um ponto de incompletude na metonímia alucinada que engendra seu gozo, que ele pode ou não - realizar o apelo que aloja o analista em sua economia psíquica. Eis a matriz pulsional da transferência e do trabalho com o significante e o gozo no chiste; eis uma oportunidade para que o analista, também no exercício de sua responsabilidade, não ceda ante a psicose.

Recebido em 2/7/2008. Aprovado em 18/8/2008. 


\title{
REFERÊNCIAS
}

FREIRE, A. B.; BASTOS, A.(2006) "Alíngua e a clínica com o falante". In: BASTOS, A. (Org.) Psicanalisar hoje. Rio de Janeiro: Contra-Capa, 2006, v. 1, p.30-41.

FREUD, S. (1987) Edição standard das obras completas de Sigmund Freud. Rio de Janeiro: Imago Editora.

(1905) “O chiste e sua relação com o inconsciente”, v. VIII, p.13267.

(1912) “Dinâmica da transferência”, v. XII, p.131-147.

(1914) “Sobre o narcisismo: uma introdução”, v. XIV, p.89-119.

(1915) "O inconsciente”, v. XIV, p.183-245.

(1920) “Além do princípio do prazer”, v. XVIII, p.13-89.

LACAN, J. (1960/1998) "Subversão do sujeito e dialética do desejo no inconsciente freudiano”. In Escritos, Rio de Janeiro: Jorge Zahar.

LACAN, J. (1955-56/1988) O seminário livro 3, As psicoses. Rio de Janeiro: Jorge Zahar.

.(1968-1969/2008) O seminário livro 16. De um outro ao Outro. Rio de Janeiro: Jorge Zahar.

.(1969-70/1992) O seminário livro 17. O avesso da psicanálise. Rio de Janeiro: Jorge Zahar.

.(1971-1972) O seminário livro 19. O saber do psicanalista. Inédito.

(1972-73/1985) O seminário livro 20. Mais ainda. Rio de Janeiro: Jorge Zahar.

.(1975-76/2005) O seminário livro 23. O sinthoma. Rio de Janeiro: Jorge Zahar.

MILLER, J. A. (Org.). (2005) Los inclassificables de la clínica psicoanalítica. Buenos Aires: Paidós.

RIBEIRO, M. M. C. (2006) O R.I.S.O. na clínica das psicoses. Rio de Janeiro: 7 Letras.

\author{
Ana Beatriz Freire \\ freireanab@hotmail.com \\ Carlos Alberto Ribeiro Costa \\ carloscosta.psi@gmail.com
}

